\title{
Civil Defense as a Scientific Research Area
}

\author{
Dr Jan Pilżys* \\ The University of Szczecin, Department of Humanities, the Institute of Politics and European Studies \\ Department of Peace Operations and Reacting in Crisis, ul. Krakowska 71/79 71-017 Szczecin
}

*Corresponding Author: Dr Jan Pilzys, the University of Szczecin, Department of Humanities, the Institute of Politics and European Studies. Department of Peace Operations and Reacting in Crisis, ul. Krakowska 71/79 71-017 Szczecin

\begin{abstract}
The subject of the research is civil defense $(C D)$ in Poland. The author stresses that the defense of every state from military threats is one of the main problems of modern warfare. In addition, he familiarizes us with the genesis of civil defense, the main purpose of the research and the specific objectives in the following categories: cognitive, theoretical and practical. In the light of the formulated research problems and accepted limitations, the subject of the dissertation and the research hypothesis are presented, which in the diagnostic part states that the Polish civil defense is imperfect as for today. The shortcomings are visible especially in the preparation phase (planning, organization) of its potential to combat war risks. This also applies to resource management.
\end{abstract}

In order to prove the truth of the thesis, the dissertation was divided into chapters, which at the same time will constitute the implementation of tasks in the accepted research process.

Keywords: Defense of the State, Military Policy, Civil Defense, Scientific Research

\section{INTRODUCTION}

The main task of the state is the defense against military threats. Its preparation is one of the main problems of modern warfare. The population of a given country that can not effectively counteract the effects of armed conflict will be decimated and the state will cease to exist.

Hence, the use of defensive capabilities to wage war against the aggressor and minimizing the effects of their use of weapons is a great challenge for the defense system of every state, including its military and non-military components ${ }^{1}$. In Poland, military policy is one of the elements of national security policy, especially in the conceptual and decision-making sphere of creation, preparation and use of the armed forces in times of peace, crisis and war.

It consists of the following policies: foreign, in the following dimensions: political-strategic, institutional and operational, multilateral cooperation with the North Atlantic Alliance and the European Union (EU), armament, dealing with the acquisition and operation of equipment and armaments and the support of the domestic defense industry, scientific, understood as the activity of the state and organizations and scientific institutions acting on its behalf. Its goal is to manage the development of science, to stimulate this development, to link research and development with specific areas of socio-economic life, and the practical use of the results of scientific and technological progress that would meet the needs of the state's defense system ${ }^{2}$. This is done by carrying out scientific research - understood as a multi-stage process of internally differentiated activities aimed at providing researchers with objective and exhaustive knowledge of the selected fragment of natural, technical, social or cultural realities by means of scientific methods ${ }^{3}$.

\footnotetext{
${ }^{1}$ National Security Strategy of the Republic of Poland, 2014, p. 43.

${ }^{2}$ W. Janusz (ed.), Elements of the economics of industry, Szczecin 1996, p. 462.

${ }^{3}$ W. Zaczyński, Research work of a teacher, Warsaw 1995.
} 
At present, civil defense requires a comprehensive transformation and adaptation to the current political, military and socio-economic situation of the country, including international obligations ${ }^{4}$. This particularly concerns increasing the participation of the research and development community in the area analyzed by the author. This effort can achieve the intended goal if it is a planned action and the "selected scientific institutions" will take part in it. This in turn creates a necessity to unify the views on the processes taking place in the modern field of armed conflict and the related needs of innovative solutions to protect the population from threats. It is about working out a system of cooperation between science and civil defense organizations and the whole of society, which, with the least possible effort, human effort, time and costs, will make it possible to best solve the problems.

Implementing new ideas requires courageous decision-makers. Thinking only in terms of a narrowly understood personal interest is a behavior that is detrimental to improving the protection of the population from the effects of war hazards. We must understand that we are not only architects of our own fate, but also of those who have entrusted us with their own safety. It is not an easy task, but it's a feasible one to some extent. Its implementation will enable the public to survive in any crisis situation.

Accordingly, it is necessary to distribute the force measured by the resources available between the elements of the state's defense system to achieve the set objectives. Such action will allow for proper preparation (measuring, predicting) and effectively reacting to threats with the potential of the system. The essential hard resources, in this context, will be the "population, territory, natural resources, size of economy, armed forces and political stability ${ }^{5}, \ldots$...soft power: the attractiveness of one's ideas or the ability to induce others to shape their own foreign policy in a way allowing to take into account the preferences expressed by others",

The resources forming the strength of the state should also be based on the existing historical heritage, which is the essence of what we know of the issues that have already taken place and have some impact on the future protection and defense of the population during a possible war. This requires the decision-makers to have a thorough historical knowledge that allows them to understand the element of reality and to evaluate it. It provides the basis for further study, helps to organize the knowledge gained for current and future generations of managers in the management of civil defense potential during the war ${ }^{7}$. In the case of Polish civil defense, its activity should be evaluated in the years 19732017.

\section{Polish Civil Defense - History And The Present}

The beginning of civil defense in Poland dates back to 1973. Its activity continues with some changes to the present times. The territory of Poland was inside the so-called "buffer zone" separating the Soviet Union from the potential hazards of the west. In this zone there were two groups of states: incorporated into the Soviet Union and subjected to Soviet domination. The time and specificity of this subordination was different. Civil defense functioned in accordance with the doctrine of war applied in allied forces of the Warsaw Pact. Hence Polish doctrinal views on the character of the future war, including the use of armed forces and civil defense, were mainly influenced by the Soviet views. The following factors were also a tremendous influence, namely, the experiences of the Second World War and the Nazi occupation, the open border problem of the Oder and the Lusatian Neisse, the "cold war" and the arms race, as well as the doctrines and strategic concepts of the great powers and opposing political-military pacts, the economic and demographic potential of Poland was associated with the Council of Mutual Economic Assistance. Frequent changes in the organizational structure of the armed forces, their reduction and modernization were an important issue for dependence and subordination of civil defense organizations. Worst of all, for twenty years, since the

\footnotetext{
${ }^{4}$ Regulation of the Council of Ministers of 25 June 2002 on detailed scope of action of the Head of the Civil Defense of the Country, Heads of Civil Defense of the Provinces, Counties and Communes (Journal of Laws No. 96, item.850), p. 51.

${ }^{5}$ J.S. Nye jr, International Conflicts. Introduction to theory and history, Warsaw 2009, p. 100.

${ }^{6}$ Ibidem, pg. 101.

${ }^{7}$ See more: J. Pilżys, The role and place of historical education in social life and historical culture of Poles, [in:] M. Kopczewski, D. Sienkiewicz (ed.) Education as a condition of safety in the 21st century - Uniformed services in the public security system, Koszalin 2016, pg. 305-321.
} 
creation of civil defense there has been no legal act regulating its functioning ${ }^{8}$. In addition, too late ratification of I and II of the Additional Protocol to the Geneva Conventions had its implications, in particular the First Protocol in cases of ${ }^{9}$ warning the population against threats, organizing evacuations, preparing and administering shelters, organizing blackouts, rescue, providing temporary quarters or other premises and supplies, preventing plunder and other crimes against life, health and property, temporarily restoring the functioning of the services (transport, communications, water supply, electricity, the management of reservoirs and water facilities) the help in saving stocks and other goods necessary for the survival of the civilian population, planning of organizational work related to civil defense activities.

The above indicates that in the years 1973-1992 there was a huge stagnation in the development of civil defense. It has only been since 1993 i.e. when Poland ratified the I and II Additional Protocol to this day that ten legal acts were announced as concerns its activity including:

- Ordinance of the Council of Ministers of 17 March 1993 on uniforms of persons in civil defense training (Journal of Laws No. 27, item 119), which defines the items of official and training uniforms, their pattern and color. Dark blue and black predominated. Official dresses were only available to persons during civil defense training;

- Ordinance of the Council of Ministers of 28 September 1993 on universal self-defense of the population (Journal of Laws No. 91, item 421) and defined inter alia the principles and scope of compulsory training of the population from the universal self-defense and the procedure of action of the mayors and borough leaders (presidents of cities) in this regard. The training of the population was carried out in the workplace, for the rest of the population at their place of residence no more than twice a year. They were implemented with the use of the existing civil defense training base, in the form of organized training during the time off work. Classes were taught by civil defense instructors according to previously developed training programs. The aim of the training was to master the skills: protection of one's own life and health, place of residence, work and environment and assistance to victims. The training of the universal self-defense of the population against threats was taken into account in the civil defense plans. While the imposition of obligations on the citizens in preparation for self-defense took place in the form of communal regulations ${ }^{10}$;

- Ordinance of the Council of Ministers of 28 September 1993 on Civil Protection (Journal of Laws No. 93, item 429) - its importance and impact on the security of the population during the war will be discussed later in this article;

- Ordinance of the Council of Ministers of 28 September 1993 on detailed scope of activities of the Head of Civil Defense of the Country, Heads of Civil Defense of provinces and communes as well as rules and procedures for coordinating the preparation and implementation of civil defense projects (Journal of Laws No. 91, item. 420). Their main tasks included, among others: preparation of assumptions projects and setting of the rules of civil defense, coordination of tasks and undertakings influencing the implementation of these tasks, supervision of the basic civil defense service. The head of the civil defense of the country submitted to the Minister of Defense periodic information on the state of implementation of the above tasks. The governor was responsible for directing and coordinating the preparation and implementation of civil defense projects by local government bodies, state institutions, business entities and other organizational units in the area administered by them. The borough leader performed similar tasks as the governor, and in matters

\footnotetext{
${ }^{8}$ Resolution of the National Defense Committee No. 111/73 of 18 May 1973 on the appointment of civil defense subject to the Deputy Minister of National Defense, until 1997 when civil defense was transferred to the Ministry of the Interior and Administration and subordinated to the commander of the State Fire Service.

${ }^{9}$ Geneva Conventions of 12 August 1949 on the Protection of Victims of War, ratified by Poland in 1954 (Journal of Laws No. 38, item 171) concerning the protection of civilians and the sick in active armies, improvement of the lives of the wounded, sick and shipwrecked from armed forces at sea, the treatment of prisoners of war, the protection of civilians during a war; Ratification of additional Protocols I and II, supplementary to Geneva Conventions, of 8 June 1977, ratified by Poland in 1992 (Journal of Laws No. 41, item 175 and 176).

${ }^{10}$ The Act of 8 March 1990 on Local Government (Journal of Laws of 2001, No. 142, item 1591, as amended).
} 
of civil defense he was subject to the latter. Both bodies of public administration for leading and coordinating civil defense projects could appoint a civil defense management team. The important task of the team (decision group) was to assess the crisis and to prepare conclusions from it, which needed for the decision to be made by the team leader, preparing documents (directives, guidelines, instructions) that would enable it to be put the aforesaid decision into practice. In addition, the team provided communication between the $\mathrm{CD}$ head and subordinate forces, controlled the task execution and coordinated it. Each of the operational groups was headed by a manager responsible for securing operations carried out by local CD administration bodies and CD formations. The Heads of the CD took into account, in their actions, the activities of the workplaces, subordinate to the Minister of Defense and Home Affairs, in particular in the area of alerting, warning, evacuating the population and the forces and resources allocated to rescue operations;

- The Order of the Head of Civil Defense of the State of 22 December 1994 on the design of badges for civil defense, the manner in which these badges and uniforms are worn, and the uniform standards for civil service personnel (M.P.95.6.100). To date, the civil protection sign is a blue triangle on an orange background. According to Protocol I to the Geneva Conventions, one of the vertices of the triangle is pointing upward, none of the vertices is touching the edge of the orange background. According to the regulation, this mark should be placed on permanent objects, vehicles and other equipment used by civil defense. The staff should wear it on the head cover as well as on the uniform. The mark may be made of materials which render it visible when using technical detection means;

- Ordinance of the Minister of Culture and Art of 25 April 1995 on the Protection of cultural property in the event of state security hazard and armed conflict (Journal of Laws No. 4, item 14). The concept of "cultural property" was defined by the convention on the protection of cultural property in the event of armed conflict, signed in The Hague on 14 May 1954. According to the above convention, cultural property is defined as ${ }^{11}$ : movable or immovable goods of high importance for the cultural heritage of the nation, architectural, art or historical monuments, both religious and secular, archaeological sites, building blocks of historical or artistic significance, works of art, manuscripts, books and other objects of artistic, historical or archaeological significance, as well as scientific collections and serious collections of archival books or reproduction of the above-mentioned property. Cultural property includes buildings whose principal purpose is to store or display movable cultural objects, such as museums, large libraries, archives and shelters, for the purpose of storing cultural property in the event of armed conflict, centers of a large number of cultural assets. According to the above-mentioned ordinance, the minister, in consultation with the head of civil defense of the country, elaborated rules for the protection of cultural property in the event of threats of peace, crisis and war. Apart from the general part the important elements of this ordinance were annexes containing guidelines for the development of plans for the protection of movable and stationary cultural assets in the event of a threat to state security and armed conflict and instructions on the organization of rescue of cultural property;

- Ordinance of Head of Civil Defense of the Country of 11 May 1995 on Civil Defense Service (MP95.28.332), defined the detailed organization and method of conducting civil service and exercises, the exact rules and procedures for appointment to service, basic civil defense service and the allocation card for civil defense formation, the rules and procedures for giving awards of distinctions and the imposition of disciplinary penalties, as well as the rules governing the execution and cancellation of penalties;

- Ordinance of the Minister of Interior and Administration of 18 December 1998 on specifying detailed rules for the cooperation of specialized armed protection forces with the Police, fire protection units, civil defense and communal (municipal) guards (Journal of Laws No. 161, item 1108). ). The cooperation of the civil defense formations with the Police, the municipal and fire protection guards consisted in the exchange of information on threats to public safety and public

\footnotetext{
${ }^{11}$ Official Journal of 1954, No. 46, item. 212, art. 1, also see C. Lewandowski, International cultural relations. Choice of documents and literature, Wrocław 2001, pg. 32-46, J. Pilżys, Security System of Monuments and National Heritage of the Republic of Poland [in:] J. Piątek, R. Podgórzanska (ed.), Selected aspects of security, Szczecin 2007., p. 248.
} 
order, including: artistic and sports gatherings and events, protection of places of committed crimes and offenses within protected areas, facilities of critical infrastructure of the country especially during a disaster or other local threat;

- Guidelines of the Head of the Civil Defense of the State of 13 October 1999 on the principles of elaboration of civil defense plans of provinces, counties ${ }^{12}$, communes and workplaces. The civil defense plans were confidential in their character, and as concerns work establishments a reserved one. The content of the plans was adapted to the specificity of the administrative unit. The scale of the graphic document was determined by the body preparing the plan. It consisted of descriptive and graphical part. In the descriptive part at the level of the province, the state of equipment and supplies of personal protection systems, storage facilities and workshops for repairs of equipment, protective building works, service and equipment for decontamination, protection of the population, cultural objects, blackouts and shutting down of lightening were assessed. Updates and arrangements card are included in the final part of the document. The graphic part of the CD plan included areas: formation of organizational units (formation), deployment of co-operating rescue forces, management posts of neighboring administrative units, food stores, water storage and tanks, repair shops, warehouses and filling stations, hospitals and roads to temporary accommodation;

- Guideline of the Head of Civil Defense of the State of 2 December 1999 on the principles and procedure of conducting inspections by civil defense authorities and other organizational units of civil defense tasks;

- Ordinance of the Council of Ministers of 25 June 2002 on detailed scope of activities of the Head of Civil Defense of the State, heads of civil defense of provinces and counties and communes (Journal of Laws No. 96, item 850).

- In order to best perform the above tasks, the Head of Civil Defense of the State issues guidelines every year, including ${ }^{13}$ :

$>$ the principal purpose of the civil defense activity,

$>$ main tasks of civil defense,

$>$ the purpose of civil defense preparations, in the scope of: organization, planning, threat detection, alert and warning, education, logistic security and critical infrastructure.

- Moreover, the head of civil defense of the state (CDS) issued guidelines on:

$>$ Principles of organization and method of carrying out civil protection training (2016),

$>$ Principles of preparation of the civil protection plan (2011),

$>$ principles of preparation and ensuring operation of the detection and alarming system (OCK) and the early threat warning system (SWO) in provinces, counties and communes (2010),

$>$ Norms for the supply of civil defense organs and provision of equipment, technical means and uniforms necessary for the performance of civil defense tasks, taking into account the organizational framework and the basic tasks of the civil defense formation (2014);

$>$ Rules for the evacuation of people, animals and property in the event of a mass threat (2008).

Based on the above guidelines, the heads of the civil defense of the province annually issue guidelines to the civil defense heads of the counties, the counties - to the heads of the civil defense of the commune (city).

The guidelines oblige them, among others to issue a decree on the preparation of civil defense documentation. Each of them, in the order, appoints a "team" for this purpose, stating its composition, tasks and place of meetings and guidelines for developing a civil defense plan ${ }^{14}$.

The year 1989 was a year of breakthrough for Poland, because the process of giving the armed forces a defensive character began. The arrangements of the Round Table and contract elections to the Polish

12 The Act of 5 June 1998 on county local government (Journal of Laws of 2001, No. 142, item 1592, as amended)

${ }^{13}$ Guidelines of the Head of National Civil Defense of 12 October 2016 to the activities in the field civil defense in 2017.

${ }^{14}$ Order of the President of the city of Koszalin No. 222/949 of 6 June 2012 on drawing up of civil defense documentation of the city of Koszalin. 
Parliament, uniting of Germany (1990), dissolution of the Council of Mutual Economic Assistance (1991), dissolution of the Soviet Union (1991), division of Czechoslovakia (1993), leaving the territories of European countries, including Poland, by the Soviet army by 18 September 1993, the process of creating a democracy for the lives of the nations and their armed forces was initiated in all countries, including Poland.

In the years 1990-1999 Poland found itself surrounded by new neighbors, in addition to the allied systems, in the zone of "diluted security, also called the zone of armed neutrality" ${ }^{15}$. Hence, the most urgent task of the Polish authorities was to search for a new, concept of state defense and protection of the population from the effects of military threats corresponding to future political and military changes in Europe. As a result of these searches, Poland was included in the NATO structures (1999), and in 2004 in the European Union. Since 1990 several strategic documents concerning the defense of the Republic of Poland have been in force: Defense Doctrine of the Republic of Poland (1990), followed by successive defensive strategies (defense) in 1992, 2000, 2009. In the year 2013, the Defense strategy of Poland of 2009 lost its legal force then the Political-Strategic Defense Directive was adopted, and in 2017 the Defense concept of the Republic of Poland.

The adoption of new policies, strategies, defense concepts, defense preparations and defense response plans has been a major issue for civil defense adjustment to a new situations. Its activities have encountered a number of constraints in the acquisition of resources and their rational use for the protection of society during the war. The most important thing was to find out about the goals and the way they are to be accomplished by civilian-military institutions.

At present civil defense is a non-military component of the Polish state's defense system and is a complex of internally coordinated, interdisciplinary enterprises of planning organizational, logistics and investment nature. Its most important task is to protect the civilian population from hazards and to overcome their direct effects as well as ensuring necessary conditions for it to survive ${ }^{16}$.

The author assumed that the most important ways of improving the attainment of the goals and effectiveness of civil defense activities would be to exploit the potential of science, the commercial and market sphere and the society, i.e. research centers, university researchers, government and local government administration, social organizations, active people.

At present, the use of that potential is quite a problem, both at the stage of theoretical considerations and at the stage of implementation. There is lack of knowledge and experience and appropriate methodology for smooth transition from theoretical to operational aspect. This is often because the strategic and operational objectives are inconsistent, there is lack of mutual relations and links between them and control of implementation. The strategies of communes, counties and provinces should be compatible and constitute a tool to support the implementation of statutory activities of heads of civil defense. This can be done with proper adherence to the strategic and operational objectives of the civil and military administration, with the strengthening of the existing operational subsystems of civil defense, properly organized, maintained and prepared to protect the lives, health and property of citizens ${ }^{17}$. In addition, it is imperative to increase the requirements for human resources, their knowledge and experience. In addition, there is a need to re-diagnose:

- The consistency of legislation,

- The rules of operation of each of the systems anchored in the national security system,

- The tasks of systems and their organization,

- The principles of management and financing of the strategic resources of the state,

- The objectives directing the community's actions for the purpose of common security,

\footnotetext{
${ }^{15}$ F. Puchała, People's Republic of Poland and III RP, various political conditions, various concepts of defense and safety, "Historical-Military Review", 2010, No. 4. p. 95.

${ }^{16}$ The Constitution of the Republic of Poland, 1997 - chapter I, art. 5.

${ }^{17}$ The Act of 6 April 1990 on Police (Journal of Laws No. 30, item 179).
} 
- The participation of citizens and organizations in the defense and protective tasks 18.

\section{SUBJECT AND PURPOSE OF SCIENTIFIC RESEARCH}

The current situation in Europe indicates that a possible war will be unpredictable, different from the current image of wars (classic) as an asymmetric or hybrid conflict.

So the author is rightly concerned about the issue and the question what is the next? What will be our future in the world of armaments and ongoing armed conflicts and wars? How should the society be prepared to deal with crises, in situations that are the result of a threat and that lead to a break or a significant violation of social ties? How should the structures of institutions and their potential to defend against the effects of threats be strengthened? How to convince the society that security depends on us all?

The subject of scientific research is civil defense.

The main objective of the research was to develop functional- organizational and technical solutions of using of the civil protection potential for the tasks of protecting local and regional communities during a war.

To achieve the main objective, it was decomposed into specific objectives, adopted as objectives in the following categories:

- Cognitive - analyzing the causes, ways and consequences of waging a future war; getting accustomed with war threats making analysis of the condition of the theory and practice of using the civil protection potential to protect the population from the consequences of the threats of conventional and nuclear weapons,

- Theoretical - demonstrating that safety must be an area of interest for all groups people, familiarizing them with all aspects of the development of civil defense in Poland, postulates, proposals, notions for improving the current state of civil defense;

- Practical - creating, as well as possible, an organizational model of civil defense, including: improvement of organizational structure, preparation of staff and teams of civil defense formation to carry out tasks, preparation of recommendations for civil defense heads of communes (cities), counties and provinces as concerns their own and subordinate tasks for the time of war with the use of two questionnaires developed by the author entitled: Civil defense of the Zachodniopomorskie Province in the face of war threats and Security of local communities in the Zachodniopomorskie Province. The questions in the first one concern employees, their feelings and their thoughts about the needs of the preparation, organization and management of civil defense. The second questionnaire, addressed to the public, aims to obtain information about the expectations of the society, its opinions on safety and threats in the place of residence, work and leisure, the functioning of institutions and rescue units, and the state of preparedness of society, dealing with natural disasters, civilizations and war. The questionnaire makes the society sensitive to the fact that the dangers will become increasingly unpredictable, deviating from the current image. And this in turn will require from all of us as quick adaptive solutions of defensive and protective capabilities to threats as possible.

- The presented main objective and specific objectives have raised questions that have become major research problems:

- Can the war be avoided in the future?

- Do the theoretical and practical assumptions used in civil defense strategies allow us to conclude that the available data about war and its effects are effectively used in the process of preparing the public to cope in difficult situations?

- Is it possible to combine civil defense and crisis management into one system?

- If it is possible to apply the above proposed solution, what steps should be taken to implement such a system in the proposed area and whether this solution will bring the expected benefits?

${ }^{18}$ A. Urban, Local Security, Warsaw 2009., pg. 101-110. 
On the basis of the questions asked, it was assumed that civil defense would be the subject of research, especially in terms of using its own potential and resources of the environment to effectively combat the threats of war.

For the purpose of detailing and narrowing the subject of research, the following limitations were applied to the implementation of the research process:

- In the spatial dimension, the focus was put on the civil defense of Zachodniopomorskie Province and the county of Koszalin,

- In functional terms, the effort was focused on the ability to assess the influence of the external environment on decision-making by civil defense managers in difficult situations of crisis,

- In the structural dimension the focus was limited to civil defense activities within the provincial structures, without prejudice to national conditions,

- In the dimension of data modeling the focus was limited to presenting information collected at conceptual and logical level.

Taking into account the objectives and adopted limitations as refers to the following major research problems detailed problems were formulated in the form of questions:

- To what extent does the present position of civil defense in the state defense system affect cooperation with other subsystems of the national security system?

- Which of the current civil defense elements are leading in the process of preparing and carrying out civil protection tasks during wartime?

- Are the currently used management ways of the civil defense adequate to the needs of the leader and the society?

- Is there a pattern of action in the scope of implementation of decisions on ways of counteracting military threats?

- What changes in the scope of improvement of the current state of civil protection should be recommended to heads and forces of civil defense units in Poland?

The analysis of the above research problems will allow for diagnosing the destructive situations during wars, determining their impact on state institutions, life, health, property and the environment. In addition, it will make it possible to forecast with some probability the solution of civil defense problems that may occur before, during and after the war.

The author adopted a thesis that the Polish civil defense so far was imperfect, especially in the preparation phase (planning, organization) of its potential to combat the risks of war. This also applies to resource management.

To verify such a research hypothesis it is necessary to gather the research material, to organize it and to process it. For this purpose, a method of document examination analysis, analysis and critique of writing, surveys, synthesis and deduction will be applied. In the study of structures and links of elements of systems or processes in their surrounding environment, the monographic method is planned. Methods will also be introduced to test the qualitative characteristics of structures. Methods of abstraction, generalization, and comparison may also be helpful.

Obtaining results from civil defense activities in the event of war will allow the author to develop new theorems of a general nature and logical conclusions that are indispensable for closing down the stages of research, editing the work and justifying the use of current and potential solutions in crisis management and rescue.

In the light of the formulated objectives and research problems concerning the subject matter of the research the following dissipation topic was formulated: Poland's civil defense in the face of war threats. History - the present - the future.

The work will be a problem-cognitive construction of existing solutions and future problems of civil defense management during a war. The study aims at logical ordering of many components of knowledge, including existing concepts, theorems, views, as well as materials, things and phenomena. 
The author intends to search for dependencies and links of their contents with utilization, which, once put into a required whole, can be considered as a material for deliberation, wider research, for the organization of new research works, and thus for obtaining new structural and organizational solutions to civil defense with the use of knowledge and the latest technology.

The work will consist of five chapters, an introduction and an ending, supplemented with an iconographic material, a glossary of basic definitions of concepts, and annexes documenting the contents of individual chapters.

In the first chapter, Characteristics of the Future War - causes, prevention, preparation, the author would like to make the civil defense managers realize that society is the basic point of reference to the phenomenon of war. It is the society that has a strong influence on modern political, social and military realities. It can start, deepen or terminate any bloody conflict. The author cites the deliberations of journalists and security experts who defined the war in their papers and judged it in various aspects. The chapter will highlight and characterize the causes of warfare, ways to prevent them, and preparing the society for a possible war.

Chapter Two, Characteristics of war dangers, will address potential war threats and their impact on society, i.e. they will be defined and evaluated, based on the analysis of the contemporary battlefield, the country's own civil defense capabilities, and the conditions under which it operates in the defense system of the country. The term "disaster situation of modern war" will be defined in which, as the author of the work assumes, death and threat of life will reach a level exceeding the defense potential of a given state. The developed assumptions, postulates and conclusions will indicate to the institutions responsible for defense and civil protection, what should be done to make the casualty rate as low as possible.

In the third chapter, The historical outline of the development of civil defense in Poland the main findings concerning the development of civil defense between 1921-1939 (September 1939), 19451973, 1973-2017 will be presented. The accepted censorship of time and the outline of the chapter are the result of the many socio-political and military conditions of the state. This will allow for a synthetic study of the most important issues related to the protection of the population against threats.

In the fourth chapter, Quality of civil defense strategies in the context of state security and defense, the essence of the security of man, society and the state in the modern world will be shown. Security problems should an issue of concern for the wider public, particularly with regard to all aspects of civil defense development in the area of residence, including war hazards, their effects and ways of counteracting which save life, health, property and the environment. The development of a strategy for state defense and civil defense will serve this purpose. Therefore a question should be answered what the strategy is and who should develop it? The answer to the above question will allow the author to present his own insights and solutions in order to propose ways to improve managers' work on the civil defense strategy, and to present a model of civil defense strategies and ways of implementing it.

The fifth chapter, The model of civil defense structures, will present structural solutions improving the implementation of the tasks contained in the civil defense plans, including the functioning and the course of the preparation, organization and management processes of civil defense capabilities in the event of war. The proposals will be presented in a descriptive and graphic manner.

The ending of the publication will cover the conclusions obtained from the research process, the verification of research problems and the research hypothesis set out in the introduction. Observations and conclusions can be used to rearrange an existing state or detect missing elements and tools in the analyzed civil protection structures. This will allow for a transparent completion of the civil defense formation in forces and resources, synchronizing the reaction process (command), improving the meeting of deadlines as concerns phases, stages and tasks. In addition, they will enable greater supervision of resource flows in crisis situations.

\section{SuMmary}

Today the change of the paradigm of thinking about human safety and its adaptation to the evolution of the world of threats and values is inevitable. Knowledge and experience acquired 
by security managers should be a prerequisite for assessing the risks and thus likely future security environment changes.

The emergence of increasingly new forms of threats, and their parts, components and elements forces the search for more decisive ways to counteract them. The effectiveness of reducing the negative effects of threats will depend on the resources available to the state. Their lack or inadequacy will negatively affect the performance of anti-crisis institutions in the event of a crisis.

In order to avoid the consequences of a dangerous event, civil defense managers should strive to get to know the truth about the real or potential threat - now and in the future. Understanding that will improve the management of resources and, consequently, the implementation of pre-emptive actions enabling to minimize negative consequences.

The results of the analysis of specialist literature done by the author prove that optimal solutions to civil protection problems cannot be predicted in advance. But there is a conviction among designers and professionals that it can be improved and strengthened by:

- Covering all areas of activity of anti-crisis institutions, combining them into one cooperative whole,

- Introduction of solutions that proved successful in Poland and abroad,

- Efficient use of local critical infrastructure,

- Joint identification of hazards,

- The unification of forces and command structures, co-operation and coordination, and the obtaining tangible material and training benefits and the improvement of the functioning and the security of the entities involved in rescue operations,

- Adjusting the concept of rescue team activities to the scale of the damage and the conditions in which it will operate,

- Unifying communications equipment based on new solutions that guarantee its performance in difficult terrain conditions, weather conditions, applied interference, etc.,

- Constructing common situational awareness, inter alia among the heads of civil defense and their subordinates at various levels of public administration, firefighters, policemen, soldiers, rescuers, in relation to threats and means of fighting them,

- Creating new training programs that incorporate innovative systems and technologies, the specificity of their operational use in various environmental conditions, and actions in the civil-military system.

According to those involved in civil defense, the above postulates can be realized through interviews and consultations, training sessions, symposia, conferences, staff training, which are now "one of the types of exercise used in practical development (training) of commanders and their staff. Their main aim is to prepare staff to fulfill their duties at the service level during a crisis and war, in order to improve the teamwork of organizational units and to coordinate leaders, in our case the heads of civil defense during resolving of specific tactical and operational problems related to the provision of assistance to the victims, during and after the end of military activities"19.

It should be noted that the diversity of topics in subsequent parts of the article (future monograph) demonstrates the multifaceted approach to civil defense in crisis situations and its dynamics, depending on financial, social, legal and other conditions. This obliged the author to compress the reflections, and consequently - to accept the elements of the construction of the future publication, with the aim of showing civil defense from the perspective of the needs of public safety, crisis management and rescue ${ }^{20}$.

${ }^{19}$ S. Kolcz, Staff training at tactical level. A Guide to: "The review of the Land Forces", 1993, No. 2. p.4 


\section{REFERENCES}

\section{Legislation, Ordinances and Guidelines}

[1] The Constitution of the Republic of Poland of 1997 (Journal of Laws No. 78, item 483).

[2] Ratification by Poland of the Geneva Conventions for the protection of war victims in 1954 (Journal of Laws No. 38, item 171).

[3] Ratification by Poland of Additional Protocols I and II, supplementing the Geneva Conventions in 1992 (Journal of Laws No. 41, item 175 and 176).

[4] Ordinance of the Council of Ministers of 25 June 2002 on detailed scope of activities of the Head of Civil Defense of the Country, heads of civil defense of provinces, counties and communes (Journal of Laws No. 96, item 850).

[5] Resolutions of the National Defense Committee No. 111/73 of 18 May 1973 on the appointment of civil defense.

[6] Act of 5 June 1998 on county local government (Journal of Laws of 2001, No. 142, item 1592, as amended).

[7] Act of 6 April 1990 on Police (Journal of Laws No. 30, item 179).

[8] Act of 8 March 1990 on local government (Journal of Laws of 2001, No. 142, item 1591, as amended).

[9] Guidelines for the head of civil defense of the country of 12 October 2016 for civil protection activities in 2017.

[10] Order of the President of the city of Koszalin No. 222/949 of June 6, 2012 on drawing up of civil defense documentation of the city of Koszalin.

\section{Compact publications}

[1] Balcerowicz B., Defense of a medium country, Warsaw 1997.

[2] Banulski Z., Defensive techniques, Warsaw 1996.

[3] Janusz W. (ed.), Elements of the economics of industry, Szczecin 1996.

[4] Kitler W., Civil defense (non-military) in national defense of the Republic of Poland, Warsaw 2001.

[5] Lewandowski C., International cultural relations. Selection of documents and literature, Wrocław 2001.

[6] Nye J. S. jr., International conflicts. Introduction to theory and history, Warsaw 2009.

[7] Pilżys J., Communication in crisis management and rescue systems in Poland - theory and practice, Szczecin 2015.

[8] Puchała F., People's Republic of Poland and III RP, various political conditions, various concepts of defense and safety, "Historical-Military Review", 2010, No. 4.

[9] National Security Strategy of the Republic of Poland 2014

[10] Urban A., Local Security, Warsaw 2009.

[11] Zaczyński W., Research work of a teacher, Warsaw 1995.

3. Articles

[12] Kołcz S., Staff training at tactical level. A Guide to: "The review of the Land Forces", 1993, No. 2.

[13] Pilżys J., Role and place of historical education in social life and historical culture of Poles, M.

[14] Kopczewski, Sienkiewicz D. (ed.), Education as a condition of safety in the 21 st century - Uniformed services in the public security system, Koszalin 2016.

[15] Pilżys J., Security System of Monuments and National Heritage of the Republic of Poland, [in:] J. Piątek, R. Podgórzanska (ed.), Selected aspects of security, Szczecin 2007.

\section{AUTHOR'S BIOGRAPHY}

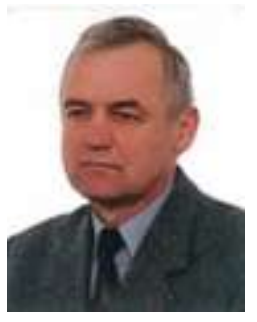

Jan PILZYS - a graduate of the Officers' School of the Anti-aircraft Defense Forces in Koszalin. In 2001, he completed his doctoral studies at the AON in Warsaw at the Military Historical Institute, obtaining a Ph.D. in humanities in the major of history. The creator of many concepts of education, training and teaching programs. The author of methodological elaborations, guides, scripts, monographs of the Military Officers' School of the Anti-aircraft Defense Forces.

Since 2004, he has been an academic teacher at the University of Szczecin. He published: Crisis Management (Szczecin 2007), Lexicon of economic security (Szczecin 2011), Planning in crisis management (Szczecin 2012), Department of Infantry of the Ministry of Military Affairs in the years 1921-1939 (Szczecin 2012), Antiaircraft defense forces in the years 1918-2013. 
Rules of tactical operations (Szczecin 2014), Communication in crisis management and rescue systems in Poland - theory and practice (Szczecin 2015). He is a co-author of the work: Defense Policy of Poland and its Armed Forces in the years 1945-1980 (Szczecin 2006). In the years 20042017, he published dozens of articles on historical issues, education and national security.

Citation: Dr Jan Pilżys. " Civil Defense as a Scientific Research Area" International Journal of Humanities Social Sciences and Education (IJHSSE), vol 4, no. 12, 2017, pp. 11-22. doi: http://dx.doi.org/10.20431/23490381.0412002 .

Copyright: (C) 2017 Authors. This is an open-access article distributed under the terms of the Creative Commons Attribution License, which permits unrestricted use, distribution, and reproduction in any medium, provided the original author and source are credited. 